\title{
An Analysis of the Performance of Unsignalized Intersection and the Impact of Vehicle Exhaust Emissions at Selokan Mataram Street
}

\author{
Wahyu Widodo ${ }^{1}$, Emil Adly ${ }^{1 *}$, Ryandika Adi Kumara ${ }^{1}$ \\ ${ }^{1}$ Department of Civil Engineering, Universitas Muhammadiyah Yogyakarta, Indonesia \\ *Corresponding author.Email: emil@umy.ac.id
}

\begin{abstract}
In transportation, Sleman Regency faces quite prevalent traffic issues, particularly traffic congestion and pollution that are caused by a surge in population mobility without being offset by sufficient development of traffic facilities and infrastructure. Therefore, a traffic management approach is needed as an alternative solution for unsignalized intersections. The technique used to collect data was traffic counting. The data were processed into an intersection performance value by using the 2014 Indonesian Highway Capacity Guidance (IHCG) and PTV VISSIM 9 Student Version software. The analysis of the 2014 IHCG produced saturation, delay, and queue probability values that met the requirement of degree saturation $(\leq 0,8)$, while the analysis results of VISSIM 9.0 were obtained after modelling the simulation of vehicle traffic flow and showed delay, length of queue, level of service, even vehicle exhaust emissions values that met requirement (Level Of Service < E). Result of VISSIM simulation deviates from IHCG due to differences in calculation system characteristics which are an interesting aspect to elaborate on. The existing condition showed the worst traffic performance with a saturation value of 1.15 and level of service E. Thus, several alternatives were made to improve the intersection performance. The second alternative shows good results for exhaust emissions.
\end{abstract}

Keywords-exhaust emissions, intersection performance, PKJI 2014, unsignalized intersection, VISSIM 9.0

\section{INTRODUCTION}

Increase in population mobility that is not offset by sufficient development in traffic facilities and infrastructure can lead to many issues. Increase in vehicle volume can also negatively affect the environment, particularly traffic-related air pollution, due to emissions as well as other traffic problems. It is proved by the increase of traffic volume that occurs every year during busy hours.

Unsignalized intersections are an at-grade junction where two or more roads meet that is not regulated by any form of Traffic Signals [1]. It is commonly found in in urban areas, especially on minor roads and/or roads where turning movements are relatively small. Unsignalized intersections are widely tolerated in low-volume traffic, with vehicle movement at unsignalized intersections is quite complicated as shown in Fig. 1. There are several general solutions for unsignalized intersections such as geometric reconstruction of formatter will need to create these components, incorporating the applicable criteria that follow. Roads to reduce queue, increasing road capacity, and enforcement of traffic management [2].

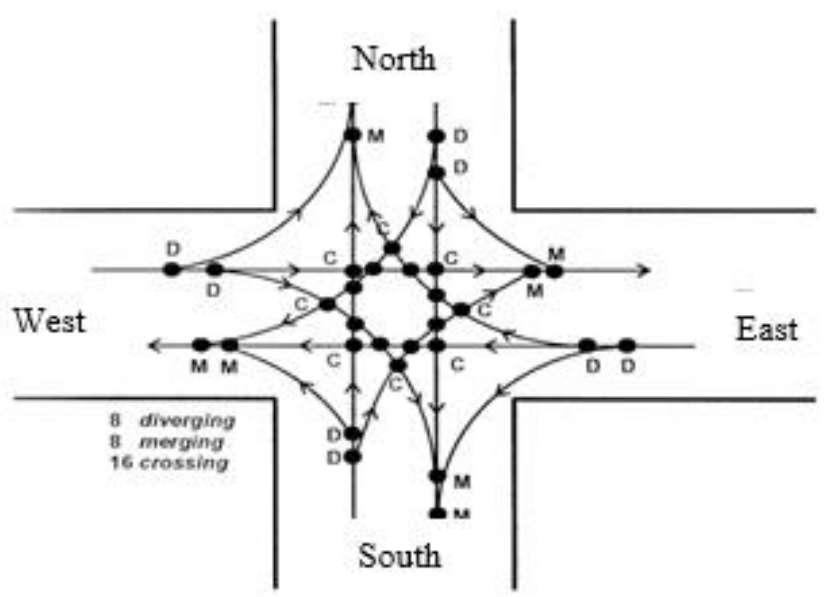

Fig 1. Movement of Intersection traffic.

There are three kinds of data that should be established to conduct an analysis of intersection performance, namely geometric data obtained from of direct observation in the field, traffic data obtained from traffic flow passing through the intersection, normally including type of vehicle within a certain period of time which is then recapitulated using an internal form [3], and intersection environment data obtained from observation and literature study, normally comprising population, city size, neighborhood type and side friction [4]. 
Capacity refers to maximum total traffic flow entering an intersection that can be maintained for at least an hour during existing weather and geometric conditions, in units of vehicle/hour. Intersection capacity calculation serves to identify the total flow entering from all segments.

Intersection traffic performance is obtained from an analysis related to capacity and delays so as to allow changes in the intersection design in the form of road geometry and traffic system regulation [5]. There are three parameters in the analysis, namely saturation level (DS), delay (T) and queue probability (PA). The determination of the performance of an intersection in relation to saturation value (DS) uses a DS standard of $\leq 0.85$. If the DS value exceeds 0.85 , a redesign to the intersection is needed to improve the operational service by the way of frontage extension or traffic management.

In Sleman Regency, the Special Region of Yogyakarta, specifically at Selokan Mataram street, also faces traffic problems at intersections. Upsurge in traffic volume occure during busy hours every year. Increase in traffic volume leads to worsening air pollution due vehicle emissions. The most effective solution to this problem is implementing traffic management planning using accurate data that have been carefully analyzed.

Traffic management is the organization, planning, direction, and monitoring of the state of traffic movement, including pedestrians, cyclists, and all types of vehicles, according to Underwood [6]. Traffic management is aimed to meet transportation needs, both present and in the future, by streamlining people/vehicle movement and identifying necessary improvements to the technical side of traffic, public transport, law, road pricing and the operation of the existing transportation system.

VISSIM is a microscopic simulation based on time and behavior developed for urban traffic models [7]. VISSIM is also defined as a traffic simulation software or tool that are used for traffic engineering, transportation planning, and microscopic city planning which are presented visually. The analysis results in the PTV VISSIM 9 software show intersection performance parameters such as average queue length (QLen), level of service (LOS), vehicle delay (VehDelay). The level of service (LOS) is the capability of a road or intersection to accommodate traffic under certain circumstances. The determination of level of service aims to define the level of service of a road or intersection with criteria by [9] as shown in Table I.

Table I. Level of Service Criteria

\begin{tabular}{|c|c|}
\hline Level of Service & $\begin{array}{c}\text { Average Control Delay } \\
\text { (second/vehicle) }\end{array}$ \\
\hline A & $0-10$ \\
\hline B & $>10-15$ \\
\hline C & $>15-25$ \\
\hline D & $>25-35$ \\
\hline E & $>35-50$ \\
\hline F & $>50$ \\
\hline \multicolumn{2}{|c}{ Source: $[9]$} \\
\hline
\end{tabular}

Air pollution refers to the infusion or presence of substance, energy or other components into ambient air by human activities causing the air quality to decrease to a certain level, rendering it useless to fulfil its function as an important component in human life, organisms and other environmental elements [10]. Air pollution is caused by combustion/exhaust emissions from vehicles that merge with ambient air/free air causing smoke from vehicles to spread freely and damage the environment and can even endanger human health. Emission itself refers to substances, energy or other components discharged by an activity to open air, whether it has the potential as a pollutant or not. The analysis results of emissions in PTV VISSIM 9 Student Version obtain levels of carbon monoxide (CO) and nitrogen oxides (NOx) pollutants. These are compounds that pose negative consequence on human health such as respiratory problems, weakening of the body's defense system, slowing reflexes and even death.

\section{RESEARCH METHOD}

This study is organized systematically and in order as expected. It is organized as follows:

\subsection{Data collection}

A traffic survey was carried out directly or indirectly which included data on geometric conditions, traffic conditions, environmental conditions as well as location and population data located at an unsignalized intersection of Selokan Mataram street with Wahid Hasyim street, Condongcatur, Sleman for two days.

\subsection{Analysis and modelling}

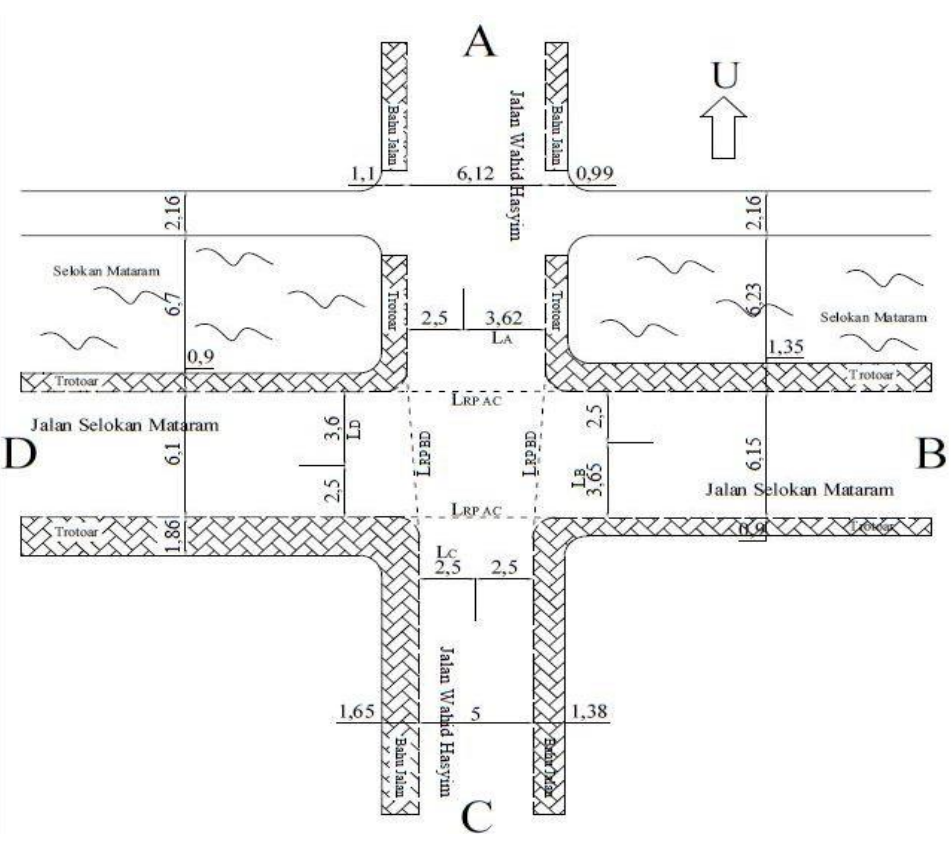

Fig 2. Geometric Intersection of Selokan Mataram Street

Fig. 2 describes the existing conditions of the intersection to be carried out by the research. The east and west side are $6.1 \mathrm{~m}$ slightly wide, and the south side is $5 \mathrm{~m}$. The north side is $6.12 \mathrm{~m}$ bigger. Uniquely the north side has other arms on the west and east sides by $2.1 \mathrm{~m}$, respectively. 


\subsection{Analysis and modelling}

A calculation analysis was carried out using the results of the traffic survey recapitulation with the 2014 IHCG 2014 as the reference and traffic simulation modeling was carried out using the PTV VISSIM 9 Student Version software and the data were processed to obtain the intersection performance analysis results. VISSIM analysis also provided results of the impact of vehicle exhaust emissions.

\subsection{Alternative planning}

If the intersection performance has not met the criteria set, plan various alternative solutions for traffic problems and analyze the data using the 2014 IHCG and model them in PTV VISSIM 9 Student Version.

\subsection{Discussion and conclusions}

If the intersection performance analysis data processing has met the criteria and achieved the desired results, then a discussion of the results in this study is conducted, one of which is by comparing the results of the analysis from the two guidelines, namely the 2014 IHCG and VISSIM 9.0.

\section{RESULTS AND DISCUSSION}

\subsection{The 2014 IHCG Intersection Performance Analysis}

Stages of the unsignalized intersection performance analysis for existing conditions are as follows:

\subsubsection{Determining peak hours}

The analysis was carried out for two study days by determining the busy hours from traffic volume (skr/hour). It was summarized in Fig. 3 and Fig. 4.

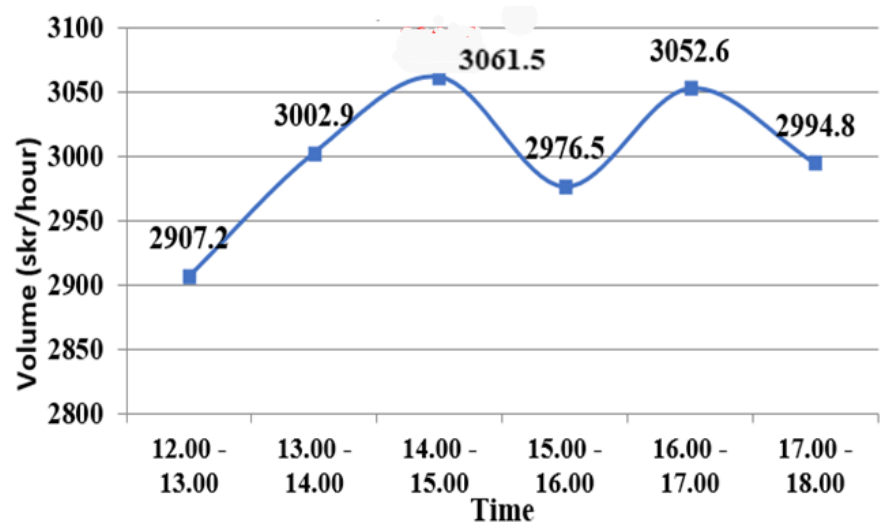

Fig 3. First day fluctuation

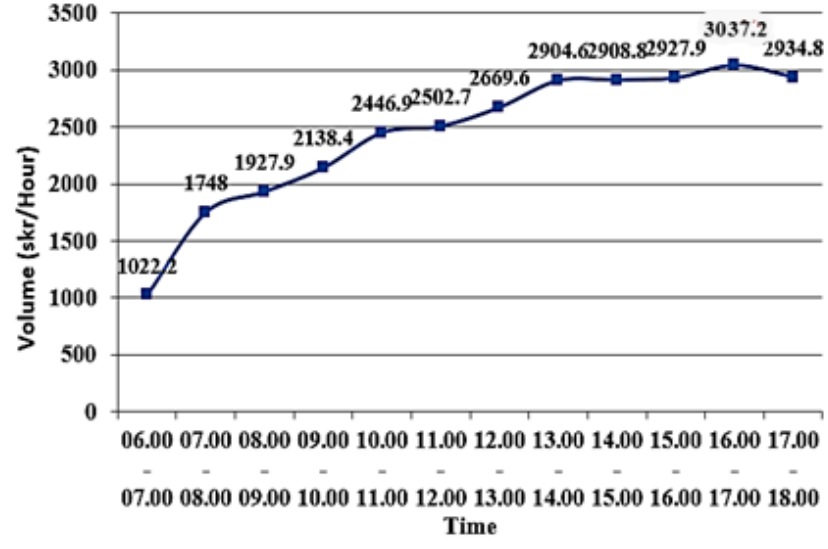

Fig 4. Second day fluctuation

Thus, we obtained the peak hour for the first day which was $14: 00$ to $15: 00$ and $16: 00$ to $17: 00$ for the second day.

\subsubsection{Inputting data}

The data inputted in the analysis process were geometric data of Selokan Mataram intersection as seen in Fig. 2, Traffic data using peak hour data from the data collection by the method of traffic counting in the field, and environmental data showing based on the observation showing that the intersection was located in a commercial area with moderate side frictions.

\subsubsection{Calculating capacity}

Identifying intersection capacity value $(C)$ using equation 1 and the results obtained from 2-day study were presented in Table II.

Table II. Intersection Capacity Value

\begin{tabular}{|c|c|c|}
\hline Value & First Day & Second Day \\
\hline $\mathrm{C}_{0}(\mathrm{skr} /$ hour $)$ & 2900 & 2900 \\
\hline $\mathrm{F}_{\mathrm{LP}}$ & 0.989 & 0.989 \\
\hline $\mathrm{F}_{\mathrm{M}}$ & 1.00 & 1.00 \\
\hline $\mathrm{F}_{\mathrm{UK}}$ & 0.94 & 0.94 \\
\hline $\mathrm{F}_{\mathrm{HS}}$ & 0.938 & 0.936 \\
\hline $\mathrm{F}_{\mathrm{BKi}}$ & 1.156 & 1.168 \\
\hline $\mathrm{F}_{\mathrm{BKa}}$ & 1 & 1 \\
\hline $\mathrm{F}_{\mathrm{Rmi}}$ & 0.910 & 0.914 \\
\hline $\mathrm{C}(\mathrm{skr} /$ hour $)$ & 2661.991 & 2696.253 \\
\hline
\end{tabular}

\subsubsection{Determining traffic performance}

Parameters used to define the intersection traffic performance studied were as follows:

a) Saturation level $\left(D_{S}\right)$, calculated using Equation 1 with the results presented in Table III.

$$
\mathrm{D}_{\mathrm{S}}=\frac{\mathrm{q}}{\mathrm{C}}
$$


Table III. Saturation Level

\begin{tabular}{|c|c|c|}
\hline Value & First Day & Second Day \\
\hline DS & 1.150 & 1.126 \\
\hline
\end{tabular}

b) Delay (T), divided into two namely traffic delay (TLL) dan geometric delay (TG) that were calculated using the equation in Table IV. Then, delay values in Table $\mathrm{V}$ were obtained.

Table IV. Delay Value Equation

\begin{tabular}{|c|c|}
\hline Value & Equation \\
\hline $\mathrm{T}(\mathrm{sec} / \mathrm{skr})$ & $\mathbf{T}=\mathbf{T}_{L L}+\mathbf{T}_{\mathbf{G}}$ \\
\hline $\begin{array}{c}\mathrm{T}_{\mathrm{LL}} \\
\text { (sec/skr) }\end{array}$ & $\begin{array}{l}\mathrm{DS} \leq 60: \\
\mathrm{T}_{\mathrm{LL}}=2+8.2078 \mathrm{DS}-(1-\mathrm{DS})^{2} \\
\mathrm{DS}>60: \\
\mathrm{T}_{\mathrm{LL}}=\frac{1.0504}{(0.2742-0.2042 \times \mathrm{DS})}-(1-\mathrm{DS})^{2} \\
(4)\end{array}$ \\
\hline $\begin{array}{c}\mathrm{T}_{\mathrm{LLma}} \\
(\mathrm{sec} / \mathrm{skr})\end{array}$ & $\begin{array}{l}\mathrm{DS} \leq 60: \\
\mathrm{T}_{\text {LLma }}=1,8+5,8234 \mathrm{DS}-(1-\mathrm{DS})^{2} \\
\mathrm{DS}>60: \\
\mathrm{T}_{\text {LLma }}=\frac{1.0503}{(0.3460-0.2460 \times \mathrm{DS})}-(1-\mathrm{DS})^{2} \\
(6)\end{array}$ \\
\hline $\begin{array}{c}\mathrm{T}_{\text {LLmi }} \\
(\mathrm{sec} / \mathrm{skr})\end{array}$ & 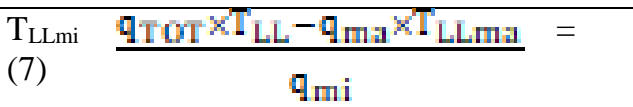 \\
\hline $\begin{array}{c}\mathrm{T}_{\mathrm{G}} \\
\text { (sec/skr) }\end{array}$ & $\begin{aligned} \mathrm{DS}<1: \mathrm{T}_{\mathrm{G}}= & (1-\mathrm{DS}) \times\left\{6 \mathrm{R}_{\mathrm{B}}+3\left(1-\mathrm{R}_{\mathrm{B}}\right)\right\} \\
& +4 \mathrm{DS} \\
\mathrm{DS}<1: \mathrm{T}_{\mathrm{G}}= & 4\end{aligned}$ \\
\hline
\end{tabular}

Table V. Delay Value

\begin{tabular}{|c|c|c|}
\hline Value & $\begin{array}{c}\text { First } \\
\text { Day }\end{array}$ & Second Day \\
\hline $\mathrm{T}(\mathrm{sec} / \mathrm{skr})$ & 30.669 & 27.760 \\
\hline $\mathrm{T}_{\mathrm{LL}}(\mathrm{sec} / \mathrm{skr})$ & 26.669 & 23.760 \\
\hline $\mathrm{T}_{\mathrm{LLma}}(\mathrm{sec} / \mathrm{skr})$ & 16.617 & 15.221 \\
\hline $\mathrm{T}_{\mathrm{LLmi}}(\mathrm{sec} / \mathrm{skr})$ & 43.104 & 38.592 \\
\hline $\mathrm{T}_{\mathrm{G}}(\mathrm{sec} / \mathrm{skr})$ & 4 & 4 \\
\hline
\end{tabular}

c) Queue probability $\left(\mathrm{P}_{\mathrm{A}}\right)$ obtained upper and lower threshold values calculated using equation 2 and 3 and the results were presented in Table VI.

Upper limit : $\mathrm{P}_{\mathrm{A}}=47.71 \mathrm{DS}-24.68 \mathrm{DS}^{2}+56.47 \mathrm{DS}^{2}$ Lower Limit : $\mathrm{P}_{\mathrm{A}}=9.02 \mathrm{DS}-20.66 \mathrm{DS}^{2}+10.49 \mathrm{DS}^{2}$
Table VI. Queue Probability Value

\begin{tabular}{|c|c|c|}
\hline $\mathbf{P}_{\mathbf{A}}$ & First Day & Second Day \\
\hline Upper Limit & 108.128 & 103.142 \\
\hline Lower Limit & 53.658 & 51.370 \\
\hline
\end{tabular}

d) Intersection traffic performance analysis that was based on standard value degree saturation (DS) of $\leq 0.85$. It was known the intersection of Selokan Mataram street and Wahid Hasyim street did not meet the requirements for proper operational service of an intersections.

\subsection{Modelling and VISSIM 9.0 Simulation}

Modelling using PTV VISSIM 9 Student Version was performed in several stages using prepared input data with the input in the form of intersection performance. The data consist of satellite maps of the location, geometric intersection, vehicle types, vehicle speed limits, and traffic volume. The modelling stages were:

2) Create background using satellite maps (Google Earth) of the Selokan Mataram intersection.

3) Create road network in accordance with the road geometric data.

4) Create vehicle routes based on movements on the intersection using 'Vehicle Routes' in VISSIM.

5) 'Conflict area' controlled vehicles so they do not collide with each other in the simulation with specified flow priority.

6) Determining and adding vehicle type model into the simulation based on vehicle type classification. Then arranging vehicle types using features like Vehicle Types, Vehicle Classes, Vehicle Compositions.

7) Filling out Vehicle Input to enter the vehicle traffic flow volume obtained.

8) Defining driver behaviors in the simulation using 'Driving Behaviors'.

9) Determining analysis area using 'Node' then initiating the simulation process with 'Simulations'.

The intersection performance analysis results from the simulation for two days of study were obtained and shown in Table VII and Table VIII. The intersection performance for the existing conditions from the VISSIM 9.0 simulation results was considered poor because it did not meet the (LOS $<$ LOS E) requirement.

Table VII. The Result Of First Day Analysis

\begin{tabular}{|l|c|c|c|c|}
\hline \multicolumn{1}{|c|}{ MOVEMENT } & Q LEN (m) & VEHS (ALL) & LOS (ALL) & $\begin{array}{c}\text { VEHDELAY } \\
\text { (ALL) }\end{array}$ \\
\hline Wahid Hasyim Street (A) to Selokan Mataram Street (B) & 12.14 & 42 & LOS B & 11.13 \\
\hline Wahid Hasyim Street (A) to Wahid Hasyim Street (C) & 20 & 27 & LOS_B & 13.8 \\
\hline Wahid Hasyim Street (A) to Selokan Mataram Street (D) & 20.29 & 29 & LOS D & 29.83 \\
\hline
\end{tabular}




\begin{tabular}{|c|c|c|c|c|}
\hline MOVEMENT & Q LEN (m) & VEHS (ALL) & LOS (ALL) & $\begin{array}{c}\text { VEHDELAY } \\
\text { (ALL) }\end{array}$ \\
\hline Selokan Mataram Street (B) to Wahid Hasyim Street (A) & 168.9 & 42 & LOS_F & 132.05 \\
\hline Selokan Mataram Street (B) to Wahid Hasyim Street (C) & 155.7 & 34 & LOS F & 126.62 \\
\hline Selokan Mataram Street (B) to Selokan Mataram Street (D) & 155.7 & 28 & LOS_F & 106.25 \\
\hline Wahid Hasyim Street (C) to Wahid Hasyim Street (A) & 153.7 & 62 & LOS F & 59.25 \\
\hline Wahid Hasyim Street (C) to Selokan Mataram Street (B) & 152.8 & 50 & LOS_F & 66.28 \\
\hline Wahid Hasyim Street (C) to Selokan Mataram Street (D) & 140 & 49 & LOS_F & 57.98 \\
\hline Selokan Mataram Street (D) to Wahid Hasyim Street (A) & 0.84 & 89 & LOS A & 3.55 \\
\hline Selokan Mataram Street (D) to Selokan Mataram Street (B) & 0.84 & 76 & LOS_A & 4.33 \\
\hline Selokan Mataram Street (D) to Wahid Hasyim Street (C) & 2.72 & 80 & LOS A & 7.59 \\
\hline Result & 82.71 & 608 & LOS_E & 42.13 \\
\hline
\end{tabular}

Table VIII. The Result Of Second Day Analysis

\begin{tabular}{|c|c|c|c|c|}
\hline MOVEMENT & Q LEN (m) & $\begin{array}{l}\text { VEHS } \\
\text { (ALL) } \\
\end{array}$ & LOS (ALL) & $\begin{array}{c}\text { VEH DELAY } \\
\text { (ALL) }\end{array}$ \\
\hline Wahid Hasyim Street (A) to Selokan Mataram Street (B) & 17.95 & 39 & LOS C & 16.41 \\
\hline Wahid Hasyim Street (A) to Wahid Hasyim Street (C) & 33.19 & 26 & LOS_C & 22.31 \\
\hline Wahid Hasyim Street (A) to Selokan Mataram Street (D) & 32.26 & 22 & LOS E & 43.64 \\
\hline Selokan Mataram Street (B) to Wahid Hasyim Street (A) & 52.34 & 98 & LOS_E & 43.5 \\
\hline Selokan Mataram Street (B) to Wahid Hasyim Street (C) & 36.97 & 80 & LOS D & 32.13 \\
\hline Selokan Mataram Street (B) to Selokan Mataram Street (D) & 36.97 & 70 & LOS_D & 33.22 \\
\hline Wahid Hasyim Street (C) to Wahid Hasyim Street (A) & 165 & 26 & LOS F & 210.33 \\
\hline Wahid Hasyim Street (C) to Selokan Mataram Street (B) & 164.1 & 22 & LOS_F & 241.02 \\
\hline Wahid Hasyim Street (C) to Selokan Mataram Street (D) & 139.4 & 17 & LOS F & 283.29 \\
\hline Selokan Mataram Street (D) to Wahid Hasyim Street (A) & 2.34 & 100 & LOS_A & 6.49 \\
\hline Selokan Mataram Street (D) to Selokan Mataram Street (B) & 2.34 & 90 & LOS A & 6.92 \\
\hline Selokan Mataram Street (D) to Wahid Hasyim Street (C) & 7.68 & 87 & LOS_B & 11.67 \\
\hline Result & 65.12 & 677 & LOS_E & 43.15 \\
\hline
\end{tabular}

\subsection{Traffic Problem Alternatives}

Looking at the results of the analysis of the existing traffic performance conditions at the intersection of Selokan Mataram street with Wahid Hasyim street, both references showed a poor assessment. Therefore, it was necessary to implement alternative traffic problems in order to improve the performance of intersections in accommodating the volume of vehicle traffic passing in high volume conditions.

\subsubsection{Alternative 1}

Vehicle movement traffic engineering in frontage $\mathrm{C}$ or south segment by diverting Wahid Hasyim Street into a oneway road heading north. The results of the intersection traffic performance analysis based on the 2014 IHGC and VISSIM 9.0 were presented in Table IX.

Table IX. The Result Of Alternative Analysis 1

\begin{tabular}{|c|c|c|c|}
\hline Reference & Value & First Day & Second Day \\
\hline \multirow{3}{*}{ PKJI 2014 } & Ds & 1.070 & 1.065 \\
\cline { 2 - 4 } & $\mathrm{T}(\mathrm{sec} / \mathrm{skr})$ & 22.838 & 22.537 \\
\cline { 2 - 4 } & $\mathrm{PA}(\%)$ & $46-92$ & $46-91$ \\
\hline \multirow{3}{*}{ VISSIM 9.0 } & LOS & LOS_E & LOS_E \\
\cline { 2 - 4 } & VEHDELAY (sec) & 37.120 & 41.250 \\
\cline { 2 - 4 } & QLEN (meter) & 61.490 & 63.220 \\
\hline
\end{tabular}

\subsubsection{Alternative 2}

Vehicle movement traffic engineering in frontage D or west segment by diverting Wahid Hasyim Street into a oneway road heading east. The results were presented in Table X.

Table X. The Result Of Alternative Analysis 2

\begin{tabular}{|c|c|c|c|}
\hline Reference & Value & First Day & Second Day \\
\hline \multirow{3}{*}{ PKJI 2014 } & Ds & 0.862 & 0.870 \\
\cline { 2 - 4 } & T (sec/skr) & 10.689 & 10.866 \\
\cline { 2 - 4 } & PA (\%) & $30-59$ & $30-60$ \\
\hline \multirow{2}{*}{$\begin{array}{c}\text { VISSIM } \\
9.0\end{array}$} & LOS & LOS_D & LOS_C \\
\cline { 2 - 4 } & VEHDELAY (sec) & 30.130 & 20.560 \\
\cline { 2 - 4 } & QLEN (meter) & 41.230 & 27.640 \\
\hline
\end{tabular}

\subsubsection{Alternative 3}

Combination of reduction in sidewalk width in major roads and vehicle movement traffic engineering on frontage $\mathrm{D}$ by diverting Selokan Mataram street into a one-way road heading east similar to the second alternative. The results were shown in Table XI. 


\subsection{Comparison of the IHGC 2014 and VISSIM Analysis}

Analysis using two different references produced different results in the same conditions for two days of study. Because of this reason, the results of the analysis that had been carried out show differences in the characteristics of the calculation analysis. From the two references, it can be seen from the delay in Fig. 5 and Fig. 6.

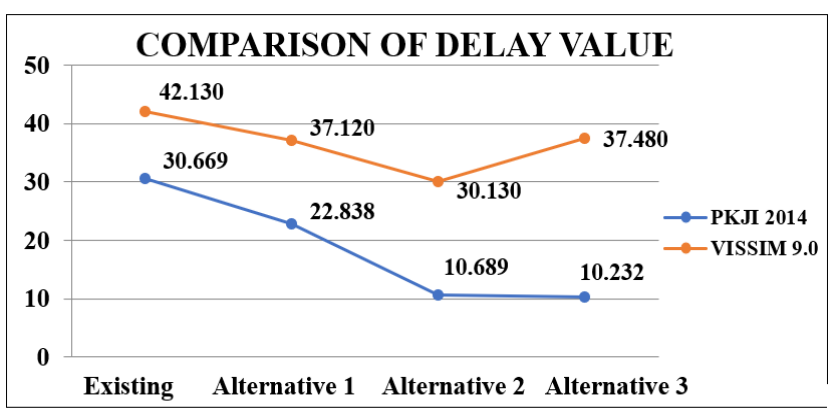

Fig 5. Delay comparison on first day

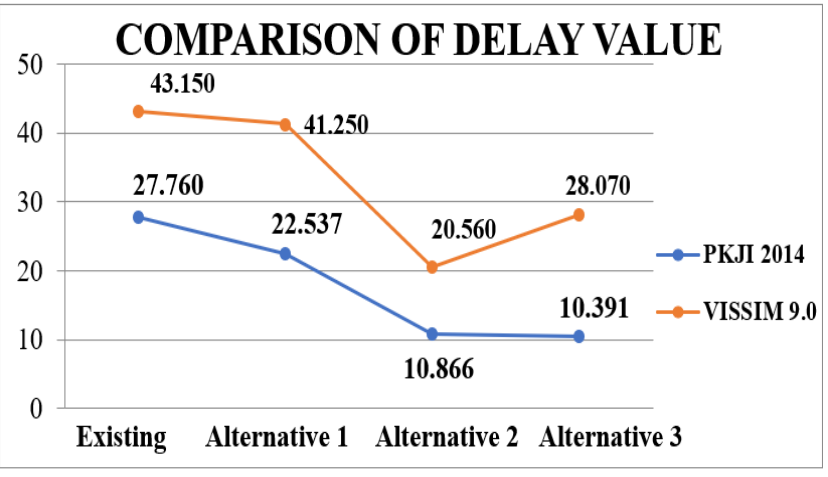

Fig 6. Delay comparison on second day

\subsection{Exhaust Emissions Analysis}

The values of vehicle exhaust emissions impact obtained from the traffic modelling simulation analysis with VISSIM 9.0 for each condition in two days were presented in Table XII The data above showed that alternative 1 showed the worst exhaust emission substance value and fuel consumption from vehicle traffic activities.

Table XI. Comparison Of Intersection Services On The First Day

\begin{tabular}{|c|c|c|c|c|c|c|}
\hline \multirow{2}{*}{ Condition } & \multicolumn{3}{|c|}{ PKJI 2014 } & \multicolumn{3}{c|}{ VISSIM 9.0 } \\
\cline { 2 - 7 } & $D s$ & $T(S e c / s k r)$ & $P_{A}(\%)$ & $L O S$ & $V E H D E L A Y(S e c)$ & $Q L E N($ meter $)$ \\
\hline Exsisting & 1.150 & 30.669 & $54-108$ & LOS_E & 42.130 & 82.710 \\
\hline Alternative 1 & 1.070 & 22.838 & $46-92$ & LOS_E & 37.120 & 61.490 \\
\hline Alternative 2 & 0.862 & 10.689 & $30-59$ & LOS_D & 30.130 & 41.230 \\
\hline Alternative 3 & 0.841 & 10.232 & $28-56$ & LOS_E & 37.480 & 46.410 \\
\hline
\end{tabular}

Table XII.Comparison Of Intersection Services On The Second Day

\begin{tabular}{|c|c|c|c|c|c|c|}
\hline \multirow{2}{*}{ Condition } & \multicolumn{3}{|c|}{ PKJI 2014 } & \multicolumn{3}{c|}{ VISSIM 9.0 } \\
\cline { 2 - 7 } & $D_{S}$ & $T(S e c / s k r)$ & $\mathrm{P}_{\mathrm{A}}(\%)$ & $D S$ & $T(S e c / s k r)$ & QLEN (meter) \\
\hline Exsisting & 1.126 & 27.760 & $51-103$ & LOS_E & 43.150 & 65.120 \\
\hline Alternative 1 & 1.065 & 22.537 & $46-91$ & LOS_E & 41.250 & 63.220 \\
\hline Alternative 2 & 0.870 & 10.866 & $30-60$ & LOS_C & 20.560 & 27.640 \\
\hline Alternative 3 & 0.849 & 10.391 & $29-57$ & LOS_D & 28.070 & 37.990 \\
\hline
\end{tabular}

Table XIII. Result Exhaust Gas Emissions

\begin{tabular}{|c|c|c|c|c|c|c|}
\hline \multirow{2}{*}{ Condition } & \multicolumn{3}{|c|}{ First Day } & \multicolumn{3}{c|}{ Second Day } \\
\cline { 2 - 7 } & $\begin{array}{c}\text { Emissions } \\
\text { CO } \mathbf{( g r})\end{array}$ & $\begin{array}{c}\text { Emissions } \\
\text { NOx } \mathbf{( g r})\end{array}$ & $\begin{array}{c}\text { Fuel Consumptions } \\
\text { (gal) }\end{array}$ & $\begin{array}{c}\text { Emissions } \\
\text { CO }(\mathbf{g r})\end{array}$ & $\begin{array}{c}\text { Emissions } \\
\text { NOx }(\mathbf{g r})\end{array}$ & $\begin{array}{c}\text { Fuel Consumptions } \\
\text { (gal) }\end{array}$ \\
\hline Exsisting & 905.676 & 176.212 & 12.957 & 964.372 & 187.632 & 13.796 \\
\hline Alternative 1 & 1010.049 & 196.519 & 14.45 & 1078.661 & 209.868 & 15.431 \\
\hline Alternative 2 & 780.966 & 151.948 & 11.173 & 634.581 & 123.466 & 9.078 \\
\hline Alternative 3 & 981.556 & 190.975 & 14.042 & 808.122 & 157.231 & 11.561 \\
\hline
\end{tabular}

\section{CONCLUSION}

Based on the results of unsignalized intersection between Selokan Mataram street and Wahid Hasyim street, Depok, Sleman, the Special Region of Yogyakarta, the following conclusions were drawn:

1) The unsignalized intersection performance analysis that used the 2014 Indonesian Highway Capacity Guidance (IHCG) showed poor results with DS value of 1.15 and 1.13 for the first and second day, respectively. 
2) The unsignalized intersection simulation modelling using the PTV VISSIM 9 Student Version software showed level of service (LOS) of E or poor, average queue length (QLEN) of \pm 42 meters and vehicle delay (VEHDELAY) of \pm 73 seconds that are summarized for two days of study.

3) The solution to the traffic performance problems at the Selokan Mataram street intersection is presented in three alternatives. Based on the 2014 IHCG, the best alternative is the third alternative with a DS value of 0.84 and 0.85 for the first day and the second day, respectively. Based on VISSIM 9.0, the best alternative is the second alternative with service levels (LOS) D and C for the first day and the second day, respectively.

4) The second alternatives shows the best exhaust emission analysis results compared other alternatives.

5) The comparison of the results of the intersection traffic performance analysis using the two references implies that the way the 2014 IHCG analysis does not really take into account how much traffic flows in and out of the intersection, what counts is the overall performance of the intersection. The VISSIM 9.0 analysis takes into account the traffic flow in and out of the intersection.

\section{REFERENCES}

[1] Bina Marga. Manual Kapasitas Jalan Indonesia. Directorate General of Bina Marga, Jakarta, 1997.

[2] A. Munawar. Manajemen Lalu Lintas Perkotaan, Beta Offset, Yogyakarta, 2004.

[3] Indonesia, R. P. K. J. Rancangan Pedoman Bahan Konstruksi Bangunan dan Rekayasa Sipil Kapasitas Jalan Bebas Hambatan. Ministry of Public Housing, 2014.

[4] Kementrian PU, 2014, Pedoman Kapasitas Jalan Indonesia, Ministry of Public Housing, Jakarta.

[5] J. D. Ansusanto, S. Tanggu. "Analysis of Performance and Management in Intersection with High Density" [Analisis Kinerja dan Manajemen pada Simpang dengan Derajat Kejenuhan Tinggi], Dinamika Rekayasa, 12, 7986, 2016.

[6] Risdiyanto. "Rekayasa dan Manajemen Lalu Lintas, Teori dan Aplikasi, Leutikaprio Nouvalitera, Yogyakarta.

[7] D. Haryadi, I. Tajudin, \& Muchlisin. Modul of Traffic Micro-Simulation Program PTV VISSIM 9, Laboratory of Transport, Dept. of Civil Engineering UMY, Yogyakarta, 2017.

[8] Peraturan Menteri Perhubungan Nomor KM 14 Tahun 2006 about Management and Traffic.

[9] HCM, 2010, Highway Capacity Manual. Washington, D.C.: Transportation Research Board.

[10] Peraturan Pemerintahan Nomor 41 Tahun 1999 tentang about Mitigation of Pollution. 